\title{
Hereditary ectodermal dysplasia with hypohydrosis: A report of two female siblings with autosomal recessive type inheritance
}

\author{
${ }^{*}$ M B K C Dayasiri ${ }^{1}$, S T Kudagammana ${ }^{1}$, H B Jayaweera ${ }^{1}$, S Krishnapradeep ${ }^{1}$, S Kasthuriarachchi ${ }^{2}$
}

Sri Lanka Journal of Child Health, 2016; 45(3): 218-220

DOI: http://dx.doi.org/10.4038/sljch.v45i3.7886

(Key words: Hereditary ectodermal dysplasia; hypohydrosis)

\section{Introduction}

Ectodermal dysplasia is typically inherited as an Xlinked recessive trait so that frequency and severity is more pronounced in males than females ${ }^{1}$. We report two female siblings born to healthy, consanguineous parents who had hypohydrotic ectodermal dysplasia (HED) with autosomal recessive inheritance pattern.

\section{Case report}

Twelve and seven year old female siblings born to healthy, second degree consanguineous parents from Dickoya were referred for further evaluation of dysmorphic facies with dental, hair and skin abnormalities. Both children had skin peeling during neonatal period and were intolerant of hot water and warm environment. Both children had history of dry mouth and difficulty in swallowing.

Both had typical facies of ectodermal dysplasia that were characterized by frontal bossing; malar hypoplasia; a flattened nasal bridge; recessed columella; thick, everted lips; wrinkled, hyperpigmented periorbital skin and prominent, lowset ears. The skin was dry, fine and wrinkled. The scalp hair was sparse, fine, and lightly pigmented. Both children had absent eyebrows and lashes. Body hair was also absent. Both children had hypodontia with widely spaced, conical teeth (Figures 1 and 2). Nails were normal and not involved. Both children had reduced saliva production but tear production

${ }^{1}$ University Paediatric Unit, Teaching Hospital, Peradeniya, ${ }^{2}$ Base Hospital, Dickoya

*Correspondence: mbkcdayasiri@gmail.com

(Received on 29 December 2014: Accepted after revision on 20 February 2015)

The authors declare that there are no conflicts of interest

Personal funding was used for this project. Open Access Article published under the Creative Commons Attribution

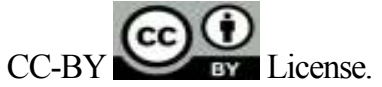

was normal. There was no history of candida infections and no clinical or biochemical evidence of Addison disease or hypoparathyroidism. Audiological evaluation found left sided conductive hearing loss in the younger sibling. Skin biopsy confirmed the diagnosis of hypohydrotic ectodermal dysplasia in both siblings.

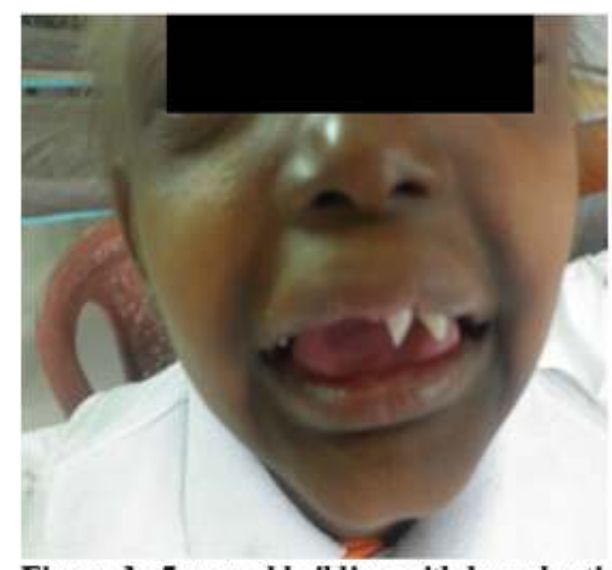

Figure 1: 7 year old sibling with hypodontia and widely spaced conical teeth

*Permission given by parents to publish photograph

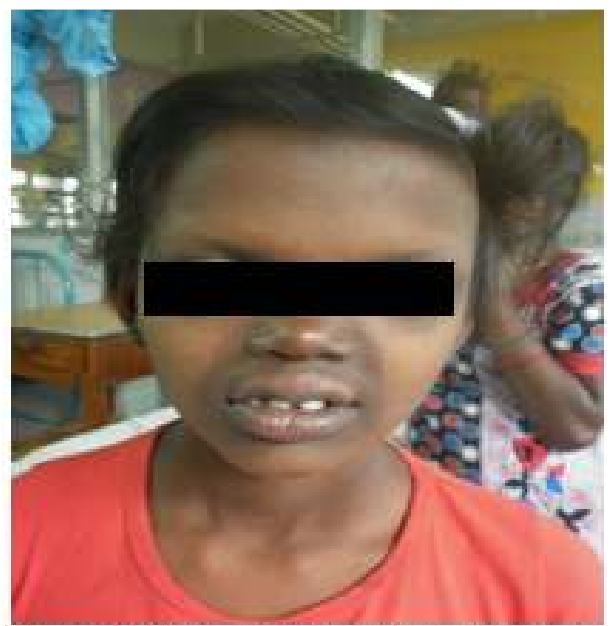

Figure 2: 12 year old sibling with less prominent features

*Permission given by parents to publish photograph 


\section{Discussion}

Clinical findings in autosomal recessive anhidrotic ectodermal dysplasia are identical to those of the Xlinked recessive disorder, except that females are affected to the same degree as males. Given the fact that both these children are girls, and their parents are unaffected and second degree consanguineous, inheritance of their illness is most likely to be autosomal recessive. Though the overall prevalence of ectodermal dysplasia is 1 in $17,000^{2}, 80 \%$ such cases have Christ-Siemens-Touraine (CST) syndrome which is inherited as X-linked recessive. It has an incidence in males of $1 / 50,000$ to $1 / 100,000$ births. Autosomal recessive inheritance is much rarer, and in fact the existence of an autosomal recessive form of the disorder had been proposed but subsequently had been challenged by the hypothesis that the phenotype of severely affected daughters born to unaffected mothers in these rare families may be due to marked skewing of X inactivation ${ }^{3}$. Recently, however in one study five families with possible autosomal recessive HED were identified, on the basis of the presence of severely affected females and multiple affected family members ${ }^{3}$. Similarly a gene responsible for autosomal HED has recently been mapped to chromosome 2q11-q133. Most often, the parents of an individual with an autosomal recessive disorder are carriers of one copy of the altered gene but do not show signs and symptoms of the disorder. Even though X-linked and autosomal recessive forms are phenotypically similar, identification of the way of transmission is mandatory to offer reliable genetic counselling to the family.

Extensive peeling of the skin is a clinical clue to diagnosis of HED in the newborn period. The paucity of sebaceous glands may account for the dry skin. Underdevelopment of mucous glands within the respiratory and gastrointestinal tracts can lead to dyspnoea and dysphagia respectively. Otolaryngeal and ophthalmologic abnormalities are secondary to decreased saliva and tear production respectively.

The presentation of thin eyebrows and partial anodontia observed in our cases is in agreement with existing literature ${ }^{1}$. However, the observation of normal form and shape of finger and toenails in the present cases is in accordance with previous observation of Shaw et $\mathrm{al}^{4}$. The fact that three generation family pedigree showed no other affected family members and parents were second degree consanguineous supports the rarer autosomal recessive type inheritance in these two female siblings.
Both children exhibited xerostomia in agreement with previous reports ${ }^{2}$ and this could be attributed to rudimentary development of accessory salivary glands. Both children had repeated episodes of hyperthermia as with existing literature ${ }^{2}$ and could be explained by defective development of skin appendages such as hair follicles, sebaceous and sweat glands. Though previous reports have described defective lacrimation ${ }^{5}$, both children in the current report had intact tear production.

First classification system of ectodermal dysplasia was published in $1994^{6}$. It was based on hair, nail and dental anomalies together with eccrine gland dysfunction or dyshydrosis. Both children we report had all clinical features except nail abnormalities. Treatment of children with hypohidrotic ectodermal dysplasia includes protection from exposure to high ambient temperatures. Early dental evaluation is necessary so that prostheses can be provided for cosmetic reasons and for adequate nutrition. The prognosis of ectodermal dysplasia is good and lifespan of the patient is usually normal except for those with immunodeficiency.

\section{References}

1. El- Tony MK, Fetelh RM. Hereditary hypohidrotic ectodermal dysplasia with anodontia: a case report. Saudi Dental Journal 1994; 6(1):31-4.

2. Varghese G, Sathyan P. Hypohidrotic ectodermal dysplasia - a case study. Oral \& Maxillofacial Pathology Journal 2011; 2: 124-6.

3. F. Munoz, G. Lestringant, V. Sybert et al. Definitive evidence for an autosomal recessive form of hypohidrotic ectodermal dysplasia clinically indistinguishable from the more common X-linked disorder. American Journal of Human Genetics 1997; 61 (1): 94-100. http://dx.doi.org/10.1086/513905 PMid: 9245989 PMCid: PMC1715866

4. Shaw RM. Prosthetic management of hypohidrotic ectodermal dysplasia with anodontia. Case report. Australian Dental Journal 1990; 35(2):113-6. http://dx.doi.org/10.1111/j.18347819.1990.t b05873.x

PMid: 2346400 
5. Beckerman BL. Lacrimal anomalies in anhidrotic ectodermal dysplasia. American Journal of Ophthalmology 1973; 75(4):72830.

http://dx.doi.org/10.1016/00029394(73)9083 $0-1$
6. Pinheiro M, Freier Maia N. Ectodermal dysplasia: A clinical classification and casual review. American Journal of Medical Genetics 1994; 53(2): 153-62.

http://dx.doi.org/10.1002/ajmg.1320530207 PMid: 7856640 